\title{
Statistical analysis of the grain morphology of the present and fossil cereals
}

\author{
ROMUALD KOSINA \\ Institute of Botany, University of Wroclaw, ul. Kanonia 6/8, \\ 50-328 Wroclaw, Poland \\ (Received: July 9, 1979)
}

\begin{abstract}
The grains of the following present-day cereal forms were charred: Secale cereale, Triticum aestivum var. compactum, var. vulgare and Avena sativa. For each caryopsis before and after charring width, thickness, length and weight were determined. The charring caused the increase of the coefficient of variation in the majority of cases, but proportionally to variation of the characters of the uncharred grains. The second group of anaylsed material were the grains of the present and fossil cereals. In the material six features of grain morphology were investigated. For present and fossil cereals the matrices of simple correlation were calculated. By means of analysis of multiple regression the interdependence of grain weight and its dimensions was investigated. The introduction into the equation of regression of successive independent variable (grain dimensions) causes a progressive exhaustion of the total variability of the regressand (grain weight). The weight of grain is equally a representative trait as well as its dimensions. This feature may serve for comparative studies of populations of fossil grain of the very same species originating from various periods or sites. This type of analysis may illustrate the influence of selection on the size of grain.
\end{abstract}

\section{INRODUCTION}

The morphology of grain (shape, dimensions, weight) is a very significant element of evaluation of contemporary cereals. It is also important for the estimation of fossil materials and especially in comparative analysis. For fossil materials most frequently the average dimensions in the grain population and their range are given (W i e s e r o w a, 1967; Was ylikowa, 1973). These features as well as the observed shape of the caryopsis are used in specific classification of fruits. They are as a rule the most important features accessible to measurement of the 
fossil material. However, situations occur when we deal with a large quantity of grain, e.g. cereals in granaries, originating from the same soil-climatic region, but from various historical periods. Here the investigator is not interested in the difference of the dimensions of wheat and rye grain, but the differences in the features of the grain of wheat from various periods. If the grain of definite cereal species in the $X$ century was small, and in successive centuries underwent a gradual increase of dimensions, then we can speak of the conscious activity of man in improvement of the cultivated populations. Such an analysis will be correct in the case of relatively large samples with comprehensively analysed distribution of the features. The equality of the means and of the ranges of two samples does not prove the likeness of the distributions and thereby the likeness of the investigated populations. The above mentioned requirement of the large size of the sample in the case of comparison of many populations increases considerably the laboriousness of the analysis. The reduction of the number of the investigated features or the choice of other features equally representative and easier in measurement can make the analysis simple and can accelerate it. The purpose of the present investigations is to indicate that the weight of the caryopsis is exactly sure a feature. The author, using the results obtained by means of multivariate analysis (multiple regression), presents the possibilities to extend the conclusion as well as the methodical basis to complex analysis of fossil material which was at his disposal. To compare the samples by means of grain weight, it is necessary to fulfil certain reqiurements:

1 - we investigate the whole grain (without wastage) and

2 - we assume a similar way of charring of the material. The introductory part of the paper contains data concerning changes of some features of the grain after charring. Charring is an additional element of the variation of the material, therefore, one should take it here into account.

\section{MATERIAL AND METHODS}

The grains of various present as well as fossil cereals were the research material. The grain of Bromus secalinus was also included in the analysis. Part of the fossil material was obtained from the Institute of Botany, Polish Academy of Sciences in Cracow. The list of investigated species and varieties is given in Tables 1 and 3 . The taxonomy of the genus Triticum is given according to Bowden and Sears (Morris, 
Sirs, 1970). Six features of each caryopsis were determined: width, thickness, length, weight, volume and coefficient of shape. To the determination of grain weight a torsion balance was used, which makes possible precise and quick estimation. The grain volume was calculated according to the formula: $\mathrm{V}=\frac{1}{6} \pi \mathrm{abc}$ ( $\mathrm{a}, \mathrm{b}, \mathrm{c}$ - dimensions of grain; $\mathrm{V}$ - volume of the three-axial ellipsoid); the coefficient of shape informing about the elongation of grain by formula: $\varphi=\sqrt[3]{\frac{2 c}{a+b}}(c-$ length; $\mathrm{a}, \mathrm{b}-$ width and thickness of the grain). For the sphere $\varphi=1$. The measurements of the features were carried out on $n=100$ (for the present wheat populations) or $n=50$ size of a sample (for the remaining populations).

\section{Statistical background}

Two statistical parameters were given for the investigated features: the mean and the coefficient of variation. The coefficient of variation is here most the suitable parameter to characterize the variability of the sample. In the case of equal means it additionally differentiates the populations (Fig. 1). In analysis of multiple regression ( $\mathrm{M} \mathrm{i} \mathrm{c} \mathrm{h}$ ałowski, 1968; Bartkowiak, 1978) the grain weight was adopted as regressand (y), and the dimensions as the cause variables (x). This assumption is adequate for the equation: $y=b_{0}+b_{1} x_{1}+b_{2} x_{2}+$ $+b_{3} x_{3}$, where $b_{1}, b_{2}, b_{3}$ are partial coefficients of regression in the following sequence: $\mathrm{x}_{1}-$ width, $\mathrm{x}_{2}-$ thickness and $\mathrm{x}_{3}-$ length of grain. The difference of the total variation of the observed y-variable and residual variation remaining after elimination from the y-variable of its estimate by means of the linear function of $\mathrm{x}$-variables is here the measure of regression variability. It is expressed by the value of the coefficient of determination (square of the coefficient of multiple correlation) by the formula: $R_{y}^{2}=\frac{T V-R V}{R V}(T V-$ total variation; $R V-$ residual variation). The significance of partial coefficients of regression was estimated by the t-test and the coefficient of determination by the F-test. Skewness and kurtosis of distributions were calculated by the generally accepted formulae ( $\mathrm{Bartkowiak}, 1978$ ) and were tested according to $\mathrm{Schmidtke}$ and $J$ äger (1976). The above parameters allow to characterize the populations according to Figs 2, 3 and 4. Supplementary testing of distribution normality by the chi square-test may be carried out. 


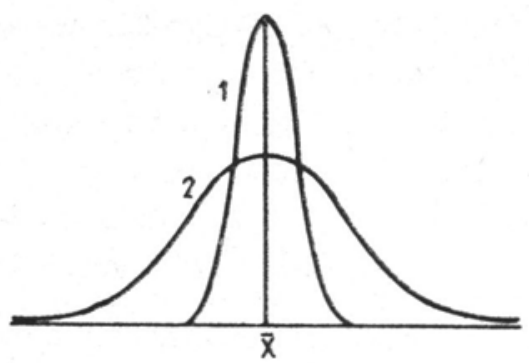

Fig. 1. Twu distributions with equal means and a small (1) and large (2) vałue of the coefficient of variation ( $x-$ mean).

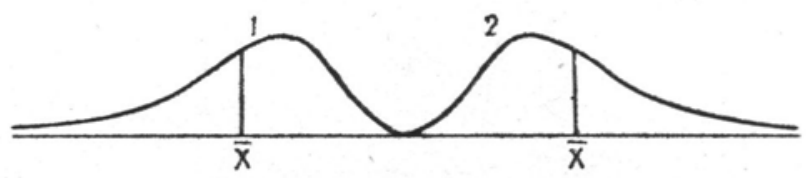

Fig. 2. Negatively (1) and positively (2) skewed curve. ( $\bar{x}-$ mean)

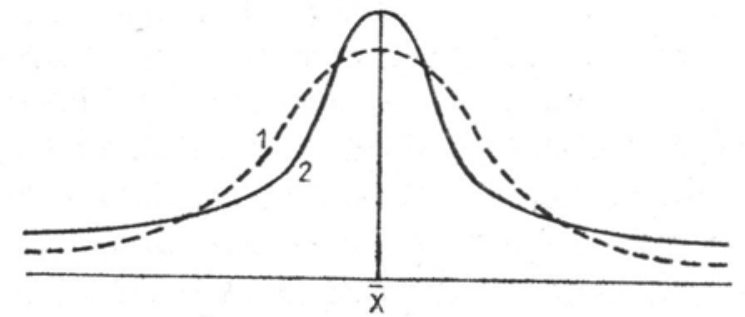

Fig. 3. Normal (1) and leptokurtic (2) distribution. ( $\overline{\mathbf{x}}-$ mean)

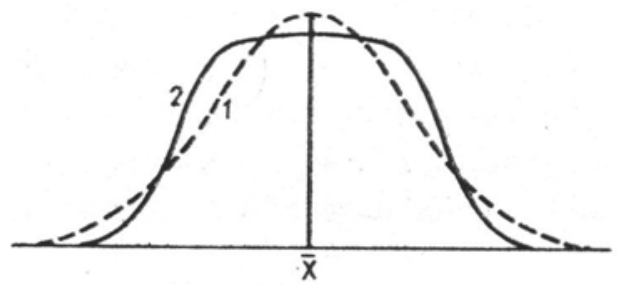

Fig. 4. Normal (1) and platykurtic (2) curve. ( $\bar{x}-$ mean)

\section{RESULTS AND DISCUSSION}

A. Variation of features of grains as influenced by charring

The charring of grains under natural conditions (temperature of charred wood) causes significant changes in their dimensions and weight. Tables 1 and 2 present the results. The width and thickness of the 
grain increase, the length and weight decrease. The data of the width of the grains are analogical to Hopf's earlier results (1955) for other species of cereals. It is necessary here to remark that charring effects an increase in the variability of features (in Table 1 a few exceptions from this are visible). A very large increase in the variation of weight is observed in husked Avena sativa grains. The structure of glumes and their close connection with the caryopsis is here the cause of the different resistance of grain against charring. In view of the above mentioned statement one should not make use of grain weight for comparative analysis of charred husked grains. As a rule such grains are characterized by unequal charring down. Table 2 shows changes in the dimensions after charring in two categories of grains: 1 - with 13\% moisture, and 2 - dried to constant weight. Both categories undergo significant changes during charring. Significant differences were noted between the two categories in the width of grain of the 'Rokicka' wheat cultivar and in the length of Avena sativa. In these two cases the moist grains undergo wider changes after charring. The difference between the two categories will likely be more often and more distinctly revealed within a larger range of moisture. The above suggestion may be the basis to the following statement: grain stored in moist sites may undergo considerably greater deformations when charred than when it is dry. And vice versa: observation of the degree of deformation of grain may show the conditions under which it was stored.

\section{B. Variation of morphological features of present and fossil cereal grain}

The data of grain morphology are listed in Table 3 . The weight and volume are characterized by relatively wide variation. The width and thickness reveal smaller variation $(10 \%)$ and the length of grain shows still lower variation. The coefficient of shape has the lowest variability. This shows the usefulness of the last feature for classification. The charred fossil forms of grains mostly show a small increase of characters variability, which one should attribute to the charring. The very high variation of weight of millet from Wrocław should be explained as follows: these are uncharred grains whose contents enclosed in glumes rotted to various degrees (likewise as previously charred Avena sativa). The observation of means indicates that fossil rye is considerably smaller than the present-day grains, despite the assumption of the increase of some their dimensions during charring. The volume value of grain shows more clearly the differences of the size of the present and fossil cereals. The coefficient of shape indicates particularly the generic and somewhat less distinctly the specific differences (peculiarity of shape). 
Table 1

Changes of the dimensions and weight of grain under the influence of charring

\begin{tabular}{|c|c|c|c|c|c|c|c|c|c|}
\hline \multirow{2}{*}{\multicolumn{2}{|c|}{ Forms of cereals }} & \multicolumn{2}{|c|}{ Width } & \multicolumn{2}{|c|}{ Thickness } & \multicolumn{2}{|c|}{ Length } & \multicolumn{2}{|c|}{ Weight } \\
\hline & & $\bar{x}$ & V & $\bar{x}$ & V & $\bar{x}$ & $\mathbf{V}$ & $\bar{x}$ & V \\
\hline \multicolumn{10}{|l|}{$T$. aestivum var. vulgare: } \\
\hline 'Rokicka' a & a & $3.28 \mathrm{x}$ & 12.8 & $2.82 \mathrm{x}$ & 11.1 & $6.08 x$ & 7.3 & $40.0 x$ & 27.8 \\
\hline $\mathrm{b}$ & b & 4.22 & 13.8 & 3.28 & 14.1 & 5.33 & 9.8 & 9.9 & 32.1 \\
\hline 'Erynaceum 2' a & a & $3.07 x$ & 9.0 & $2.86 x$ & 8.7 & $6.15 x$ & 7.3 & $36.7 x$ & 20.0 \\
\hline & b & 3.88 & 11.2 & 3.20 & 10.0 & 5.10 & 9.3 & 8.4 & 20.8 \\
\hline 'Odesska 26' a & a. & $2.94 \mathrm{x}$ & 8.6 & $2.75 \mathrm{x}$ & 5.8 & $6.02 \mathrm{x}$ & 4.7 & $34.8 x$ & 17.3 \\
\hline & b & 3.80 & 8.8 & 3.17 & 8.8 & 5.28 & 7.8 & 9.2 & 25.4 \\
\hline$T$. aestivum var. compactum & a & $3.14 \mathrm{x}$ & 10.6 & $2.94 \mathrm{x}$ & 7.2 & $6.37 x$ & 6.4 & $39.6 x$ & 22.0 \\
\hline & b & 3.99 & 9.4 & 3.60 & 11.6 & 5.54 & 8.8 & 10.7 & 22.1 \\
\hline Secale creale & a & $2.77 x$ & 13.4 & $2.85 x$ & 9.0 & $8.83 \mathrm{x}$ & 8.7 & $44.7 x$ & 25.1 \\
\hline , & b & 3.82 & 10.7 & 3.38 & 12.7 & 7.76 & 10.2 & 8.3 & 30.4 \\
\hline Avena sativa (husked) & a & $2.70 \mathrm{x}$ & 7.0 & $2.20 \mathrm{x}$ & 6.6 & $9.12 \mathrm{x}$ & 10.8 & $32.7 x$ & 24.6 \\
\hline & b & 3.55 & 9.0 & 3.10 & 10.6 & 8.14 & 10.6 & 12.0 & 62.3 \\
\hline Avena sativa (unhusked) & a & $2.40 \mathrm{x}$ & 8.3 & $1.96 \mathrm{x}$ & 8.0 & $7.06 x$ & 10.6 & $23.3 \mathrm{x}$ & 24.2 \\
\hline & b & 3.41 & 11.1 & 2.92 & 12.0 & 6.04 & 13.6 & 6.5 & 30.1 \\
\hline
\end{tabular}

$\bar{x}$ - mean (mm, mg)

$\mathrm{V}$ - coefficient of variability (per cent)

a - before charring

b - after charring

$x-$ the difference between means significant at alpha $=0.001$ ( $t-$ test) 
Table 2

Characterization of dimensions of the grain before and after charring (with normal moisture and dried to constant weight)

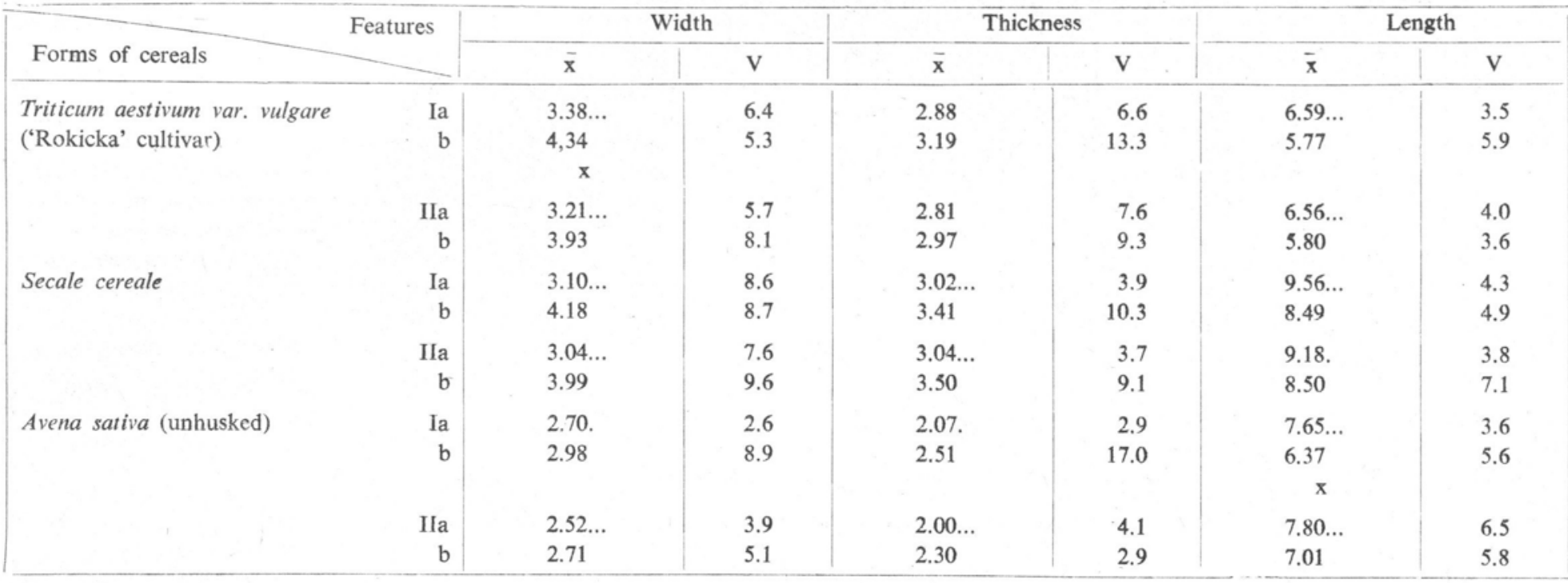

$\bar{x}$ - mean $(\mathrm{mm})$

$\mathrm{V}$ - coefficient of variability (per cent)

I - normal moisture

II-dried to constant weight

a - before charring

b - after charring

the difference between means significant at $\alpha=0.05$ (.)

$\mathrm{x}$ - the high significant difference in change of grain dependent on the gra in moisture 
Table 3

Characterization of grain morphology of present and fossil cereals

\begin{tabular}{|c|c|c|c|c|c|c|c|c|c|c|c|c|}
\hline \multirow{2}{*}{ Populations Features } & \multicolumn{2}{|c|}{ Width } & \multicolumn{2}{|c|}{ Thickness } & \multicolumn{2}{|c|}{ Length } & \multicolumn{2}{|c|}{ Weight } & \multicolumn{2}{|c|}{ Volume } & \multicolumn{2}{|c|}{ Shape } \\
\hline & $\bar{x}$ & V & $\bar{x}$ & V & $\overrightarrow{\mathrm{x}}$ & V & $\bar{x}$ & V & $\bar{x}$ & V & $\bar{x}$ & V \\
\hline \multicolumn{13}{|l|}{ PRESENT CEREALS: } \\
\hline \multicolumn{13}{|l|}{$T$. aestivum var. vulgare } \\
\hline 'Capega' & 2.80 & 16.9 & 2.68 & 11.8 & 6.77 & 7.5 & 30.8 & 34.0 & 27.3 & 31.2 & 1.35 & 3.4 \\
\hline 'Manitoba' & 2.92 & 14.1 & 2.55 & 11.6 & 5.84 & 6.4 & 29.2 & 28.3 & 23.2 & 27.0 & 1.29 & 3.4 \\
\hline 'Ostka Popularna' & 2.93 & 14.8 & 2.50 & 13.3 & 6.59 & 7.8 & 33.1 & 32.8 & 26.1 & 29.6 & 1.35 & 3.5 \\
\hline T. aestivum var. sphaerococcum & 2.74 & 13.1 & 2.66 & 10.5 & 4.75 & 7.4 & 20.7 & 27.7 & 18.4 & 26.0 & 1.21 & 3.0 \\
\hline$T$. aestivum var. spelta & 2.89 & 11.5 & 2.32 & 12.2 & 7.35 & 8.8 & 33.7 & 28.4 & 26.4 & 26.3 & 1.41 & 2.5 \\
\hline T. turgidum var. polonicum & 2.93 & 15.9 & 2.86 & 10.8 & 9.94 & 9.4 & 53.2 & 29.7 & 44.7 & 28.4 & 1.51 & 4.0 \\
\hline T. turgidum var. durum & 2.88 & 11.4 & 2.90 & 12.1 & 7.53 & 7.1 & 43.5 & 26.1 & 33.6 & 25.9 & 1.38 & 2.6 \\
\hline Secale cereale & 2.80 & 10.4 & 2.83 & 8.6 & 8.91 & 8.3 & 45.9 & 22.6 & 37.6 & 23.1 & 1.47 & 2.3 \\
\hline Avena sativa (husked) & 2.68 & 6.9 & 2.17 & 5.6 & 9.41 & 10.3 & 32.2 & 19.9 & 28.9 & 18.5 & 1.57 & 3.2 \\
\hline Hordeum distichum (husked) & 3.53 & 6.3 & 2.72 & 6.5 & 8.10 & 6.3 & 43.3 & 15.7 & 41.0 & 14.6 & 1.37 & 2.7 \\
\hline Hordeum vulgare & & & & & & & & & & & & \\
\hline 'Himalaya' (naked) & 3.37 & 10.6 & 2.44 & 10.4 & 7.35 & 8.9 & 39.3 & 26.3 & 32.3 & 25.9 & 1.36 & 2.2 \\
\hline 'Elgina' (husked) & 3.52 & 5.7 & 2.72 & 5.5 & 8.17 & 10.3 & 44.4 & 15.4 & 41.3 & 17.1 & 1.38 & 4.1 \\
\hline Panicum miliaceum (husked) & 2.02 & 7.8 & 1.58 & 5.5 & 3.04 & 2.7 & 5.1 & 13.3 & 5.1 & 11.6 & 1.19 & 2.2 \\
\hline Bromus secalinus & 1.44 & 8.2 & 1.53 & 8.3 & 6.37 & 5.7 & 7.3 & 17.4 & 7.4 & 15.6 & 1.63 & 2.3 \\
\hline Mean of the $V$ values & & 11.0 & & 9.5 & & 7.6 & & 24.1 & & 22.9 & & 3.0 \\
\hline & & & & & & & & & & & & \\
\hline
\end{tabular}


FOSSIL CEREALS:

T. aestivum var. vulgare Wroclaw, XIII century Wroclaw, second half of XI century

Przemyśl, XI-XII century

Łubomia, IX century

Secale cereale

Wrocław, XIII century

Lubomia, IX century

Wąsosz, Early Roman time Avena sativa

Wrocław, XIII century

(unhusked)

Wroclaw, second half of

XI century (husked)

Panicum miliaceum

Wrocław, second half of

XI century (husked)

Wąsosz, Early Roman time

(unshusked)

Bromus secalinus

Wrocław, XIII century

Lubomia, IX century

\begin{tabular}{|c|c|c|c|c|c|c|c|c|c|c|c|}
\hline 3.46 & 10.7 & 2.77 & 11.4 & 4.55 & 10.8 & 13.3 & 27.0 & 23.2 & 26.8 & 1.13 & 3.3 \\
\hline 3.20 & 11.6 & 2.65 & 10.4 & 4.38 & 11.4 & 12.9 & 29.3 & 19.9 & 28.2 & 1.14 & 3.1 \\
\hline 3.01 & 12.5 & 2.42 & 13.4 & 4.27 & 10.5 & 12.1 & 31.8 & 16.7 & 30.6 & 1.16 & 3.6 \\
\hline 3.08 & 11.5 & 2.57 & 10.7 & 4.58 & 8.0 & 12.1 & 22.2 & 19.3 & 24.0 & 1.18 & 3.1 \\
\hline 2.33 & 13.2 & 2.17 & 12.8 & 5.38 & 12.1 & 7.7 & 28.8 & 14.6 & 32.1 & 1.34 & 4.1 \\
\hline 2.35 & 8.8 & 2.15 & 8.6 & 5.83 & 8.7 & 9.2 & 18.2 & 15.6 & 20.1 & 1.37 & 3.1 \\
\hline 1.96 & 11.4 & 1.83 & 12.1 & 5.09 & 9.5 & 6.1 & 24.5 & 9.8 & 27.3 & 1.39 & 3.7 \\
\hline 2.30 & 9.4 & 1.96 & 10.3 & 6.34 & 10.6 & 8.9 & 24.4 & 15.3 & 26.0 & 1.44 & 3.2 \\
\hline 2.61 & 11.4 & 2.31 & 12.7 & 9.90 & 11.7 & 13.6 & 32.4 & 32.1 & 29.6 & 1.59 & 3.8 \\
\hline 2.03 & 7.7 & 1.50 & 8.8 & 2.81 & 4.7 & 1.4 & 62.5 & 4.5 & 14.4 & 1.17 & 3.7 \\
\hline 1.56 & 5.8 & 1.29 & 7.0 & 1.65 & 5.8 & 1.3 & 11.7 & 1.7 & 12.1 & 1.05 & 2.5 \\
\hline 1.75 & 10.5 & 1.37 & 9.4 & 4.61 & 8.4 & 3.2 & 22.2 & 5.8 & 22.8 & 1.44 & 3.0 \\
\hline 1.70 & 11.3 & 1.37 & 11.3 & 5.19 & 9.0 & 3.6 & 23.3 & 6.4 & 23.8 & 1.50 & 3.9 \\
\hline & 10.4 & & 10.7 & & 9.3 & & $24.7^{+}$ & & 24.4 & & 3.4 \\
\hline
\end{tabular}

$\mathrm{x}$ - mean (mm, mg, cubic $\mathrm{mm}$, an abstract number)

$\mathrm{V}$ - coefficient of variation (per cent)

+ - without Panicum miliaceum from Wroclaw 


\section{Table 4}

Simple correlation of morphological features of fossil and present cereal grain (coefficient of correlation $\times 10^{3}$ )

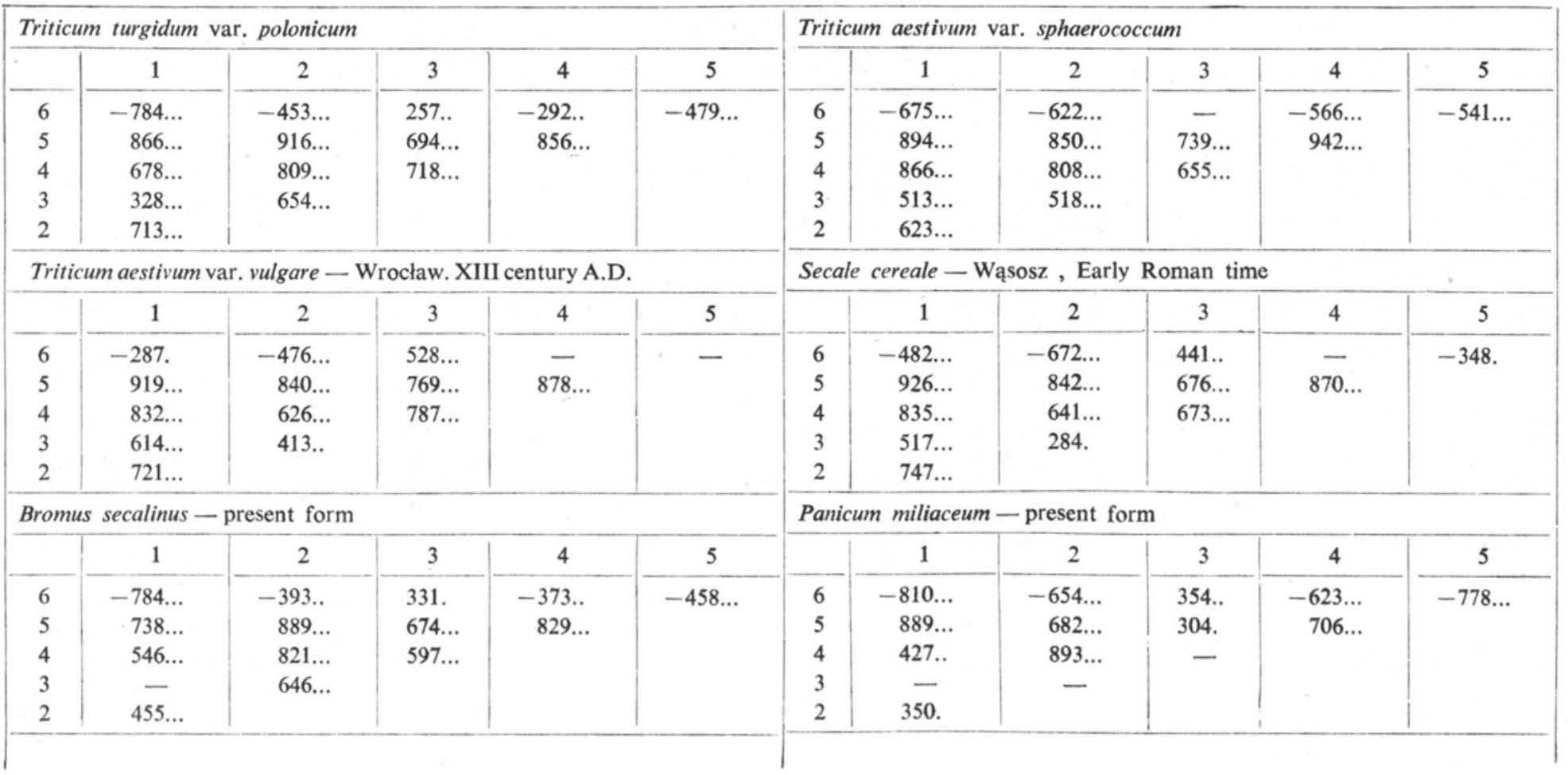


Panicum miliaceum - Wąsosz, Early Roman time

\begin{tabular}{c|c|c|c|c|c}
\hline & 1 & 2 & 3 & 4 & 5 \\
\cline { 1 - 5 } 6 & $-567 \ldots$ & $-495 \ldots$ & $723 \ldots$ & -294. & - \\
5 & $678 \ldots$ & $779 \ldots$ & $515 \ldots$ & $668 \ldots$ & \\
4 & $545 \ldots$ & $563 \ldots$ & - & \\
3 & - & - & & & \\
2 & $358 .$. & & & & \\
\hline
\end{tabular}

Bromus secalinus - Wrocław, XIII century A.D.

\begin{tabular}{c|c|c|c|c|c} 
& 1 & 2 & 3 & 4 & 5 \\
\hline 6 & $-655 \ldots$ & -309. & $498 \ldots$ & - & - \\
5 & $792 \ldots$ & $850 \ldots$ & $708 \ldots$ & $751 \ldots$ & \\
4 & $536 \ldots$ & $744 \ldots$ & $519 \ldots$ & & \\
3 & - & $527 \ldots$ & & & \\
2 & $530 \ldots$ & & & & \\
\hline
\end{tabular}

Hordeum distichum

\begin{tabular}{c|c|c|c|c|c}
\hline & 1 & 2 & 3 & 4 & 5 \\
\hline 6 & $-595 \ldots$ & $-657 \ldots$ & $578 \ldots$ & $-380 \ldots$ & - \\
5 & $901 \ldots$ & $866 \ldots$ & $633 \ldots$ & $961 \ldots$ & \\
4 & $926 \ldots$ & $887 \ldots$ & $503 \ldots$ & & \\
3 & 288. & - & & & \\
2 & $908 \ldots$ & & & & \\
\hline
\end{tabular}

Secale cereale - present form

\begin{tabular}{c|r|r|r|r|r}
\hline & \multicolumn{1}{c|}{1} & 2 & 3 & 4 & 5 \\
\hline 6 & $-496 \ldots$ & -311. & 333. & -284. & - \\
5 & $882 \ldots$ & $903 \ldots$ & $844 \ldots$ & $980 \ldots$ & \\
4 & $888 \ldots$ & $899 \ldots$ & $791 \ldots$ & & \\
3 & $593 \ldots$ & $698 \ldots$ & & & \\
2 & $704 \ldots$ & & & & \\
\hline
\end{tabular}

Panicum miliaceum - Wroclaw, second half of XI century A.D.

\begin{tabular}{c|c|c|c|c|c}
\hline & 1 & 2 & 3 & 4 & 5 \\
\cline { 2 - 5 } 6 & $-922 \ldots$ & $-844 \ldots$ & $750 \ldots$ & $-575 \ldots$ & $-757 \ldots$ \\
5 & $855 \ldots$ & $948 \ldots$ & - & $605 \ldots$ & \\
4 & $684 \ldots$ & $540 \ldots$ & - & & \\
3 & $-487 \ldots$ & -346. & & & \\
2 & $849 \ldots$ & & & & \\
\hline
\end{tabular}

Avena sativa - present form

\begin{tabular}{c|c|c|c|c|c}
\hline & 1 & 2 & 3 & 4 & 5 \\
\cline { 2 - 4 } 6 & - & - & $825 \ldots$ & $374 .$. & $359 \ldots$ \\
5 & $837 \ldots$ & $772 \ldots$ & $822 \ldots$ & $971 \ldots$ & \\
4 & $804 \ldots$ & $737 \ldots$ & $816 \ldots$ & & \\
3 & $453 \ldots$ & $362 \ldots$ & & & \\
2 & $719 \ldots$ & & & & \\
\hline
\end{tabular}

Hordeum vulgare, 'Elgina' cultivar

\begin{tabular}{c|c|c|c|c|c|}
\hline & 1 & 2 & 3 & 4 & 5 \\
\hline 6 & - & -282. & $868 \ldots$ & - & $371 .$. \\
5 & $800 \ldots$ & $761 \ldots$ & $776 \ldots$ & $735 \ldots$ & \\
4 & $873 \ldots$ & $829 \ldots$ & 289. & & \\
3 & - & - & & & \\
2 & $923 \ldots$ & & & & \\
\hline
\end{tabular}

Significance of correlation coefficient: . $\alpha=0.05$

.. $\alpha=0.01$

$\ldots \alpha=0.001$ (in table are given only significant correlations)

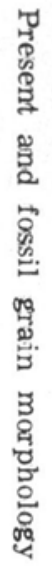

岕 
C. Simple correlation matrix analysis of morphological features

The differences between the investigated populations are evident in the interrelation of features. The features in the table of the correlation matrix (Table 4) are presented in the following sequence: 1 - width; 2 - thickness; 3 - length; 4 - weight, 5 - volume, and 6 - shape of grain. The investigated populations are characterized by the following groups of the dependence of characters:

1. wheat of polonicum type nad 'Ostka Popularna' cultivar,

2. the forms of wheat: sphaerococcum, spelta, durum, vulgare (cvs. 'Capega', 'Manitoba'), Triticum from Lubomia, barley cv. 'Hilmalaya',

3. Triticum from the XI and XIII century from Wrocław, Avena from the XI and XIII century from Wrocław, Secale XIII century from Wrocław,

4. Triticum from Przemyśl, Secale from Wąsosz,

5. Bromus - the present form, Bromus from Lubomia,

6. the present form of Panicum,

7. Panicum from Wrocław,

8. Panicum from Wąsosz,

9. Bromus from Wrocław,

10. Hordeum distichum,

11. barley cv. 'Elgina',

12. the present form of Avena,

13. the present form of Secale.

The differences between the mentioned groups are sometimes small. In most cases the features are closely correlated. Lack of correlation appears often between weight and shape as well as volume and shape of grain, therefore these features may be treated as separate characters of populations.

\section{Multiple regression analysis of features}

The close relationship between dimensions and weight of caryopsis is demonstrated in Table 5. All coefficients of determination are highly significant, irrespective of the number of variables in the regression set. Observation of the $\mathrm{R}^{2}$ value after introduction of successive independent variables indicates their share in regression variation. These variables exhaust information on the weight of caryopses variation in different degrees; and so for instance an introduction of grain length in the regression set does not modify information explained by width and thickness of caryopsis in the 'Capega' variety. The situation is differently for husked oat, where the length of grain brings additionally more than $24 \%$ of information about weight. The width exhausts only 


\section{Table 5}

Value of coefficient of determination for the dependence of caryopsis weight from cause variables in multiple regression (coefficient of determination $\times 10^{3}$ )

\begin{tabular}{|c|c|c|c|}
\hline \multirow[b]{2}{*}{ Populations } & \multicolumn{3}{|c|}{ Cause variables in the regression set } \\
\hline & Width & $\begin{array}{l}\text { Width and } \\
\text { thickness }\end{array}$ & $\begin{array}{l}\text { Width, thickness } \\
\text { and length }\end{array}$ \\
\hline \multicolumn{4}{|l|}{ FRESENT CEREALS: } \\
\hline \multicolumn{4}{|l|}{ T. aestivum var. vulgare } \\
\hline ‘Capega' & 709 & 901 & 906 \\
\hline 'Manitoba' & 840 & 949 & 961 \\
\hline ‘Ostka Popularna' & 751 & 835 & 848 \\
\hline T. aestivum var. sphaerococcum & 750 & 867 & 890 \\
\hline$T$. aestivum var. spelta & 722 & 880 & 911 \\
\hline T. turgidum var. polonicum & 459 & 676 & 764 \\
\hline$T$. turgidum var. durum & 767 & 935 & 963 \\
\hline Secale cereale & 789 & 937 & 963 \\
\hline Avena sativa (husked) & 647 & 699 & 943 \\
\hline Hordeum distichum (husked) & 858 & 870 & 940 \\
\hline \multicolumn{4}{|l|}{ Hordeum vulgare } \\
\hline ‘Himalaya' (naked) & 894 & 941 & 957 \\
\hline 'Elgina' (husked) & 763 & 766 & 770 \\
\hline Panicum miliaceum (husked) & $182 x$ & 813 & 820 \\
\hline Bromus secalinus & 298 & 711 & 730 \\
\hline \multicolumn{4}{|l|}{ FOSSIL CEREALS: } \\
\hline \multicolumn{4}{|l|}{ T. aestivum var. vulgare } \\
\hline Wroclaw, XIII century A.D. & 691 & 693 & 817 \\
\hline Wroclaw, second half of XI century A.D. & 513 & 513 & 713 \\
\hline Przemyśl, XI-XII century A.D. & 617 & 617 & 864 \\
\hline Lubomia; IX century A.D. & 666 & 736 & 819 \\
\hline \multicolumn{4}{|l|}{ Secale cereale } \\
\hline Wrockaw, XIII century A.D. & 447 & 504 & 710 \\
\hline Wąsosz, Early Roman time & 697 & 697 & 782 \\
\hline \multicolumn{4}{|l|}{ Avena sativa } \\
\hline Wroclaw, XIII century A.D. (unhusked) & 582 & 630 & 788 \\
\hline $\begin{array}{l}\text { Wrocław, second half of XI century } \\
\text { A.D. (husked) }\end{array}$ & 635 & 656 & 724 \\
\hline \multicolumn{4}{|l|}{ Panicum miliaceum } \\
\hline $\begin{array}{l}\text { Wroclaw, second half of X1 century } \\
\text { A.D. (husked) }\end{array}$ & 467 & 473 & 482 \\
\hline Wąsosz, Early Roman time (unhusked) & 297 & 453 & 485 \\
\hline \multicolumn{4}{|l|}{ Bromus secalinus } \\
\hline Wroclaw, XIII century A.D. & 287 & 581 & 607 \\
\hline Lubomia, IX century A.D. & 376 & 680 & 719 \\
\hline
\end{tabular}

All coefficients of determination significant for $a=0.001$ ( $x-$ level of significance for $a=0.01$ ) 
$45.9 \%$ of information about weight in the polonicum form and still fewer in the present forms of Panicum miliaceum and Bromus secalinus. The thickness of grain brings much information on the weight of these forms. The length of caryopsis adds but little to the information in many cases. The thickness of grain does not alter the information about weigint in the fossil wheats from Wrocław and Przemyśl as well as in rye from Wąsosz. A wide difference appears in fossil millet forms. The change of $R^{2}$ in the present millet form is similar as in the fossil unhusked form. The measurements of thickness and length do not change in fossil husked Panicum miliaceum the obtained information. The changes of $R^{2}$ are similar in fossil as well as in present forms of Bromus. The dimensions of caryopses inform about the variability of grain weight in a higher degree in present cereals than in fossil ones. However, the values of $R^{2}$ are highly significant in both cases. The data in Table 5 prove that the weight of caryopses in various present and fossil cereals is a highly representative character for the dimensions of grain, therefore it may replace them as a comparative character of populations.

\section{E. Analysis of distributions of features}

For the selected populations of present-day wheats additional characterization of the investigated features was done (Table 6). Skewness and kurtosis of the majority of distributions deviate a little from the value of normal distribution. Significant values of kurtosis indicate leptokurtic distribution, thus, the populations, in this respect, have individuals densely concentrated around the mean (Fig. 3). The significant asymmetry marked here shows negatively asymmetrical distributions (width of grain of 'Ostka Popularna', length of polonicum and durum forms) or positively asymmetrical distributions (coefficient of shape of 'Ostka Popularna' and of durum form). The types of these distributions are presented in Fig. 2. Taking into consideration the coefficient of variability in Table 3 as well as the types of distributions in Fig. 1, we may notice the differentiated variation of weight of wheats from Przemyśl and Lubomia or the similarity of this feature in wheat from the XI and XIII century in Wrocław. These elements are very significant in comparative analysis of various populations.

The presented results confirm the close correlation existing between morphological characters of cereal grain ( $\mathrm{K}$ o s i $\mathrm{n}$ a, 1974, 1978). It was confirmed moreover that the charring of grain as a rule causes an increase of variability but does not change fundamentally the existing correlation, particularly between dimensions and weight. The weight may 
Table 6

Characterization of distributions of the morphological features of grain of present-day cereals

\begin{tabular}{|c|c|c|c|c|c|c|c|c|c|c|c|c|}
\hline \multirow[b]{2}{*}{ Populations } & \multicolumn{2}{|c|}{ Width } & \multicolumn{2}{|c|}{ Thickness } & \multicolumn{2}{|c|}{ Length } & \multicolumn{2}{|c|}{ Weight } & \multicolumn{2}{|c|}{ Volume } & \multicolumn{2}{|c|}{ Shape } \\
\hline & $\mathrm{G}_{1}$ & $\mathrm{G}_{2}$ & $\mathrm{G}_{1}$ & $\mathrm{G}_{2}$ & $\mathrm{G}_{1}$ & $\mathrm{G}_{2}$ & $\mathrm{G}_{1}$ & $\mathrm{G}_{2}$ & $\mathrm{G}_{1}$ & $\mathrm{G}_{2}$ & $\mathrm{G}_{1}$ & $\mathrm{G}_{2}$ \\
\hline $\begin{array}{l}\text { 'Capega' } \\
\text { (common wheat cultivar) }\end{array}$ & -0.26 & -0.98 & -0.22 & -0.72 & -0.16 & -0.14 & 0.06 & -1.11 & -0.21 & -1.31 & 0.31 & -0.73 \\
\hline $\begin{array}{l}\text { 'Ostka Popularna' } \\
\text { (common wheat cultivar) }\end{array}$ & -1.04 & 1.39 . & -0.34 & 0.07 & 0.17 & -0.22 & -0.26 & -0.30 & -0.29 & -0.19 & $1.14 .$. & 1.04 \\
\hline T. aestivum var. sphaerococcum & -0.24 & -0.63 & -0.58 & -0.24 & -0.27 & -0.35 & -0.04 & -1.12 & -0.19 & -1.24 & 0.53 & 0.56 \\
\hline T. aestivum var. sp?lta & -0.13 & -0.11 & -0.59 & -0.36 & -0.40 & -0.59 & -0.14 & -0.64 & -0.16 & -0.75 & -0.07 & 0.25 \\
\hline T. turgidum var. polonicum & 0.25 & -0.60 & 0.26 & 0.63 & -0.90 & 1.65 . & 0.55 & 0.71 & 0.68 & 0.50 & -0.03 & -0.76 \\
\hline T. turgidum var. durum & -0.18 & -0.56 & -0.38 & -0.23 & -0.87 & 0.80 & 0.07 & -1.05 & 0.13 & -0.85 & 1.13.. & $2.41 .$. \\
\hline
\end{tabular}

$\mathrm{G}_{1}$ - coefficien of asymmetry

$\mathrm{G}_{2}$ - coefficienı of kurtosis

. significant for alpha $=0.05$

.. $\quad$ significant for alpha $=0.01$ 
be treated as a comparative character of various populations and in connection with its easy measurement it can be applied in large samples $(n=500)$. Then grain dimensions can be determined in a small sample, e.g. $\mathrm{n}=30$ and presented synthetically as the coefficient of shape. This feature has a small variation and therefore it may be used in the classification of the genus or species. It seems, however, to be of little value for characterizing various populations of the same species. The proposed analysis based on the coefficient of variability, skewness and kurtosis seems to be very useful. They reveal additional differences existing between populations. Finally one should emphasize that detailed analysis of one representative character concerns comparison of various populations of the same species.

\section{REFERENCES}

B a rtk owiak A., 1978. Opis merytoryczny programów statystycznych. Uniwersytet Wrocławski, Wrocław.

$\mathrm{H}$ opf M., 1955. Formveränderungen von Getreidekörnern beim Verkohlen. Ber. Dtsch. Bot. Ges. 68: 191-193.

K o s in a R., 1974. Zmienność i analiza regresji wielokrotnej cech morfologicznych ziarna odmian i mieszańców pszenicy jarej. Biul. IHAR 1-2: 61-68.

K o s in a R., 1978. Analiza jakości i cech morfologiczno-anatomicznych ziarna mieszańców pokolenia $F_{2}$ pszenicy jarej. Ph. D. Thesis University of Wrocław.

Micha łowski K., 1968. Rachunek regresji w ocenie wyników doświadczeń rolniczych. PWRiL, Warszawa.

M orris E. R., Sirs E. R., 1970. Citogenetika pshenicy i rodstvennykh form. In: Wheat and wheat improvement (in Russian): 33-110. Kolos, Moskva.

S chmidtke A., Jäger R., 1976. Tabellen zur Uberprüfung der Normalität von Schiefe und Exzess. Biom. Z. 18: 413-418.

Wasylikowa K., 1973. Cereals from the early medieval fortified setlement in Lubomia, district Wodzisław Sląski, southern Poland. Part: Paleoethnobotany. Folia Quaternaria 42: 54-93.

W ie serowa A., 1967. Wczesnośredniowieczne szczątki zbóż i chwastów z Przemyśla. Folia Quaternaria 28: 1-16.

Analiza statystyczna morfologii ziarna współczesnych $i$ kopalnych zbóż

Spalano ziarniaki współczesnych form żyta, pszenicy i owsa. Dla każdego ziarniaka przed i po spaleniu oznaczono szerokość, grubość, długość i ciężar. We wszystkich przypadkach stwierdzono istotne statystycznie zmiany wartości cech po spaleniu. Spalanie powodowało zwiększanie się współczynnika zmienności, lecz proporcje wielkości współczynnika pozostały takie same jak u form niespalanych. 
Wilgotność ziarna wplywa w pewnym stopniu na deformacje ziarniaków wywolane spalaniem. Drugą grupą badanego materiału były współczesne odmiany pszenicy, żyta, owsa, prosa, jęczmienia i stokłosy żytniej oraz formy kopalne tych rodzajów pochodzące z różnych regionów Polski (Przemyśl, Lubomia, Wąsosz, Wro(law). Na tym materiale dodatkowo oznaczano dwie cechy: objętość i kształt ziarniaka. Obliczono macierze korelacji prostych sześciu cech ziarniaka wszystkich badanych populacji. Materiał kopalny charakteryzuje się zmianą korelacji niektórych cech ziarna w porównaniu z formami współczesnymi. Przy pomocy analizy regresji wielokrotnej stwierdzono dużą zależność ciężaru ziarniaka i jego wymiarów. Zależności te kształtują się różnie u różnych rodzajów zbóż. Spalenie nie zmienia jednak klasyfikacyjnej wartości cech ziarniaka, a ciężar ziarniaka jest cechą równie reprezentatywną jak wymiary ziarniaka. Jako cecha wyjątkowo łatwa do pomiaru może służyć do masowych badań porównawczych populacji ziarna kopalnego tego samego gatunku pochodzącego z różnych okresów lub różnych miejsc. Ten typ analizy będzie obrazować doskonalący wpływ selekcji wykonywanej przez człowieka w dawnych wiekach na wielkość ziarna. Charakterystyka rozkładów cech oraz pomiary wymiarów i kształtu ziarniaka uzupełniają dane o badanych populacjach. 